\title{
耳下腺唾石症の臨床的検索
}

\author{
篠原正徳・左货春 喜*・田代英雄*・村上英輔* \\ 大 関 悟*・堀之内康文・河野勝 寿* $-川$ 野芳 春 \\ 岡 本 学*・中里一成・岡 増一郎
}

\section{Clinical studies of parotid calculi}

\author{
Masanori Shinohara - Haruki Saza* • Hideo Tashiro* - Eisuke Murakami* \\ Satoru Ozeri* - Yasuhumi Horinouchi • Katsuhisa Kohno* • Yoshiharu Kawano \\ Manabu Окамото* • Kazunari NaKasato • Masuichiro OKa
}

\begin{abstract}
Clinical findings from 6 cases of parotid calculi were reported.
1) There were 1 male and 5 female patients whose ages ranged from 13 to 62 years old at the first examination in our department.

2) The incidence of parotid calcili among all our sialolithiasis during the past 15 years was $1.8 \%$.

3) Swelling of parotid gland was observed in all 6 cases and 2 cases among then were simultaneously suffered from pain.

4) Calculi were located in the extraglandular duct in 2 cases, in the intraglandular main duct in 1 case and in the intraglandular portion in 1 case. In the remaining 1 case, calculi multiply appeared in all portions.

5) The number of calculus was single in 4 cases of multiple in 2 cases.

6) The size of calculus varied from a grain of sand to that of rice. In addition, parotid calculus was generally smaller than submandibular calculus.

7) Sialography proved to be a valuable diagnostic and in visualizing and localizing calculi, providing an accurate amount of glandular damage.

8) Radionuclide scannings, ${ }^{99 \mathrm{~m} T C}$-pertechnetate and ${ }^{67} \mathrm{Ga}$-citrate scanning, were useful in determining the grandular function.

9) Calculi in the intraoral portion of the extraglandular duct were removed through intraoral approach, while those in the posterior portion of the extraglanduar duct or in the anterior portion of the intraglandular main duct were removed by external incision. Total parotidectomy was performed in the disseminated multiple calculi of the intraglandular duct.
\end{abstract}

Key words: sialolithiasis, parotid calculus, parotid gland

九州大学歯学部第 2 口腔外科学教室

(主任：岡 增一郎)

* 九州大学菌学部第 1 口腔外科学教空

(主任：田代英雄)

Second Department of Oral Surgery, Faculty of

Dentistry Kyushu University (Chief: Prof.

Masuichiro Oka)

* First Department of Oral Surgery, Faculty of Dentistry Kyushu University (Chief: Prof.

Hideo Tashiro)

受付日：昭和 58 年 11 月 17 日

\section{緒}

耳下腺唾石症は顎下腺唾石症に比べてまれな疾患であ り，そのため今日まで臨床的検索も少ない、1 13).

今回，われわれは耳下腺睡石症 6 例を経験し，臨床的 検討を加えたので報告する。 
表 1 㭘索症例

\begin{tabular}{c|c|c}
\hline 症 例 & 当科初診年㱓 & 性 別 \\
\hline 1 & 13 歳 & 女 \\
2 & 18 墄 & 男 \\
3 & 28 歳 & 女 \\
4 & 50 歳 & 女 \\
5 & 53 歳 & 女 \\
6 & 62 歳 & 女 \\
\hline
\end{tabular}

表 2 当科初診までの期間ならびに他科での診断， 治療

\begin{tabular}{|c|c|c|c|}
\hline 症例 & 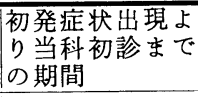 & 他科での診断 & 他科での治療 \\
\hline 1 & 2 年 & 異常なし & \\
\hline 2 & 5 か月 & 頓部の炎症 & 消炎療法 \\
\hline 3 & 20 年 & ～ & ノ \\
\hline 4 & 5 年 & 耳下腺唾石 & 経過観察 \\
\hline 5 & 3 か月 & $\overline{8} \mid$ 周囲炎 & 消炎療法 \\
\hline 6 & 1 か月 & 上顎曰蔽部の炎症 & 消炎療法 \\
\hline
\end{tabular}

\section{検 索 対 象}

検索症例は昭和 43 年 1 月より昭和 58 年 10 月までの約 15 年間に九州大学歯学部附属病院口腔外科で耳下腺唾石症 と診断した 6 症例である（表 1 ）.

\section{結果}

年齡別，性別発生頻度（表 1): 初発症状より推定し た初発年秢は約 8 歳, 11歳, 18歳, 45歳, 53歳, 62歳で あった。性別では男性 1 例, 女性 5 例で女性に多くみら れた。

当科初診までの期間ならびに他科での診断, 治療（表 2 ）：耳下腺部腫脹または疼痛などの初発症状出現時よ り当科初診までの期間は，1 か月， 3 か月， 5 か月， 2 年, 5 年, 20 年であった。他科での診断では，他科受診 した 5 例中 1 例が耳下腺唾石の診断をらけたが，他の 4 例は異常なし，もしくは煩部，且歯部の炎症の診断であ った。他科での治療では耳下腺唾石症の診断のついた 1 例は経過観察, 炎症の診断をうけた 3 例は消炎治療のみ であった。

臨床症状（表 3) : 初発症状は全例耳下腺部の 腫脹で あった，同時に疼痛も訴えたものが 2 例みられ，このう ち 1 例は摂食時痛であった。当科初診時の主訴は, 全例 耳下腺部の腫脹・疼痛であった。 また反復性耳下腺腫脤
表 3 臨床症状

\begin{tabular}{|c|c|c|c|}
\hline 症例 & 主 訴 & 初発症状 & 現 \\
\hline 1 & $\begin{array}{l}\text { 反復性耳下腺部 } \\
\text { 腫脤疼痛 }\end{array}$ & $\begin{array}{l}\text { 耳下腺部の } \\
\text { 腫脹 }\end{array}$ & $\begin{array}{l}\text { 耳下腺部腫脹・疼痛・ } \\
\text { 压痛 } \\
\text { 耳下方 } 1 \mathrm{~cm} \text { のここ } \\
\text { ろに小指頭大の腫瘤触 } \\
\text { 知 }\end{array}$ \\
\hline 2 & $\begin{array}{l}\text { 耳下腺 部の 腫 } \\
\text { 腿・压痛 }\end{array}$ & $\begin{array}{l}\text { 耳下腺部の } \\
\text { 腫脹 }\end{array}$ & $\begin{array}{l}\text { 耳介下部に } 2 \mathrm{~cm} \text { 大の } \\
\text { 腫瘤・圧痛 } \\
\text { 開口部よ年 } 5.5 \mathrm{~cm} \text { と } \\
\text { ころに唾石をブージに } \\
\text { て触知 }\end{array}$ \\
\hline 3 & $\begin{array}{l}\text { 耳下 腺部の腫 } \\
\text { 脹・疼痛 } \\
\text { 開口障害 }\end{array}$ & $\begin{array}{l}\text { 耳下腺部の } \\
\text { 腫脹 }\end{array}$ & $\begin{array}{l}\text { 耳下腺部の腫脹・硬結・ } \\
\text { 压痛開口障害 } \\
\text { 唾液の流出なし }\end{array}$ \\
\hline 4 & $\begin{array}{l}\text { 耳下 腺部の尰 } \\
\text { 脹・疼痛 } \\
\text { 唾液の味の変化 }\end{array}$ & $\begin{array}{l}\text { 耳下腺部の } \\
\text { 腫脹 }\end{array}$ & $\begin{array}{l}\text { 耳下腺部の腫脹・圧痛 } \\
\text { 開口障害 } \\
\text { 耳介前方部に大豆大の } \\
\text { 硬結触知 }\end{array}$ \\
\hline 5 & \begin{tabular}{|l} 
反復性耳下腺部 \\
腫脹・疼痛 \\
開口部よりの排 \\
膿
\end{tabular} & $\begin{array}{l}\text { 耳下腺部の } \\
\text { 腫脹・疼痛 }\end{array}$ & $\begin{array}{l}\text { 耳下腺部の腫脹 } \\
\text { 開口部の腫脹・硬結 }\end{array}$ \\
\hline 6 & $\begin{array}{l}\text { 耳下腺部の 腫 } \\
\text { 脹・疼痛 } \\
\text { 耳下腺開口部の } \\
\text { 腫脹提食時疼痛 }\end{array}$ & $\begin{array}{l}\text { 耳下腺部の } \\
\text { 腫脤・圧痛 }\end{array}$ & $\begin{array}{l}\text { 耳下腺部の腫脹・疼痛 } \\
\text { 耳下腺開口部の腫脤・ } \\
\text { 硬結・排膿 }\end{array}$ \\
\hline
\end{tabular}

表 4 唾石の存在部位, 個数, 大きさ

\begin{tabular}{|c|c|c|c|c|}
\hline 症例 & 存在部位 & 個 & 数 & 大きさ \\
\hline 1 & 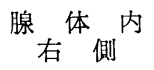 & & 個 & $4 \times 6 \mathrm{~mm}$ \\
\hline 2 & $\begin{array}{l}\text { 腺内主管内 } \\
\text { 右 側 }\end{array}$ & 1 & 個 & $3 \times 9 \mathrm{~mm}$ \\
\hline 3 & $\begin{array}{l}\text { 腺 体 内 } \\
\text { 腺内主管内 } \\
\text { 耳下腺管内 } \\
\text { 左 側 }\end{array}$ & 10数 & & 粟粒大〜米粒大 \\
\hline 4 & $\begin{array}{c}\text { 腺内主管内 } \\
\text { 右 側 }\end{array}$ & 1 & 個 & $3 \times 7 \mathrm{~mm}$ \\
\hline 5 & $\begin{array}{c}\text { 耳下腺管内 } \\
\text { 右 側 }\end{array}$ & 1 & 個 & $3.5 \times 9 \mathrm{~mm}$ \\
\hline 6 & $\begin{array}{c}\text { 耳下腺管内 } \\
\text { 左 側 }\end{array}$ & 4 & 個 & 粟粒大 \\
\hline
\end{tabular}

の既往を訴えたものも 2 例みられた。初診時症状では全 例化膿性耳下腺炎の病像を呈していた。 また全例触診に て，耳下腺腺体部または耳下腺管部に唾石様硬結を触知 した（図 1,2）.

唾石の存在部位，個数，大きさ（表 4 ）:今回, 唾石 の存在部位を大きく 3 つに分類した（図 3）.耳下腺管 (耳下腺腺体外の導管), 腺内主管 (耳下腺腺体内の耳下 腺管につづく太い導管), 腺体内（腺内主管より分枝し た導管から腺房まで). 


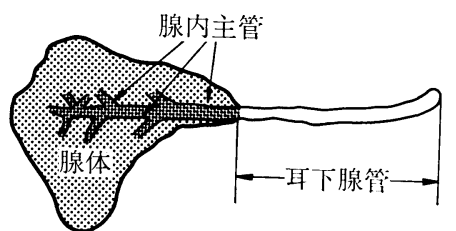

症例 1

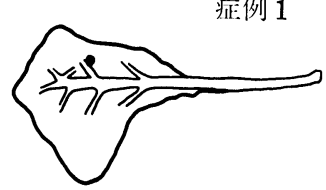

症例 3
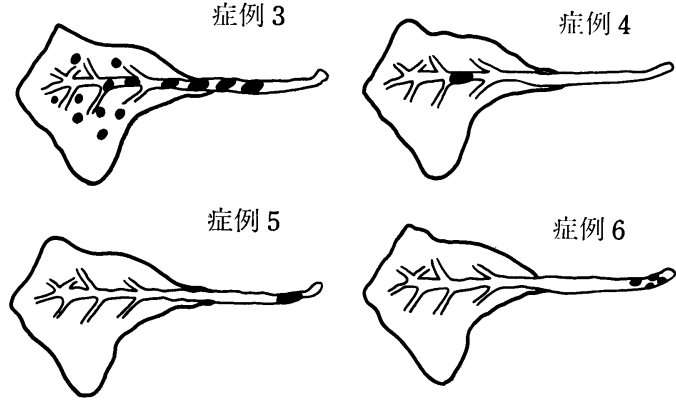

図 3 説明図

唾石の存在部位は耳下腺腺体内 1 例, 耳下腺 管内 2 例, 腺内主管内 2 例, 耳下腺腺体内, 腺内主管内, 耳下 腺管内に多発したもの 1 例であった。唾石の位置は症例 2 では耳下腺管と腺内主管の移行部近く, 症例 5,6 で は耳下腺管開口部より約 $1 \mathrm{~cm}$ 以内の部位であった。 ま た症例 4 では経過観察中に耳下腺主管内で約 $1 \mathrm{~cm}<ら$ い開口部側への唾石の移動がみられた（図 3).

唾石の個数は症例 3,6 が複数個で, 他の 4 例は 1 個 であった，複数個症例中症例 3 では耳下腺管内, 腺内主 管内, 腺体内括の打のに複数個の唾石が認められたが症 例 6 では開口部近くに集合して 4 個の唾石が認められ た。

唾石の大きさは全例 $10 \mathrm{~mm}$ 以下であった（図 4). 複 数個認められた症例 3 では, その大きさは粟粒大から米 粒大までさまざまであったが症例 6 では 4 個とも粟粒大 であった。

臨床検査 (表 5)：X線単純撮影所見では全例とも耳 下腺腺体部, 耳下腺管部に不透過像が認められた（図 5, 6 ).

耳下腺造影所見では全例とも唾石は陰影欠損像として 認められた。 また全症例とも耳下腺管または腺内導管の 抎張像がみられた。経過の長い症例 3,4 では, 腺内導 管ならびに腺系の破壊像が高度に認められた。
表 5 耳下腺造影像, RI シンチ像

\begin{tabular}{|c|c|c|}
\hline 症例 & 耳下腺造影像 & $\begin{array}{l}\mathrm{RI} \text { シンチグラフ } \\
\text { イー像 }\end{array}$ \\
\hline 1 & 腺内導管の拡張像 & \\
\hline 2 & $\begin{array}{l}\text { 腺内導管の拡張像 } \\
\text { 腺系軽度破壊像 } \\
\text { 耳下腺管内に唾石によ } \\
\text { る陰影欠損像 }\end{array}$ & $\begin{array}{l}99 \mathrm{mTc} \text { の集積状態は左 } \\
\text { 右差なし.盖なかし } \\
\text { 排出障害まり. }\end{array}$ \\
\hline 3 & $\begin{array}{l}\text { 耳下腺管, 腺内導管の } \\
\text { 不規則な㧪張像 } \\
\text { 腺系の破買像 } \\
\text { 唾石の陰影欠損像 }\end{array}$ & ${ }^{99} \mathrm{~m}$ Tc の集積欠損 \\
\hline 4 & $\begin{array}{l}\text { 腺内遒管の拡張像 } \\
\text { 腺系の破壊像 }\end{array}$ & $\begin{array}{l}{ }^{67} \mathrm{Ga} \text { の異常集積像 } \\
{ }^{99} \mathrm{~m} \mathrm{Tc} \text { 集積不良 }\end{array}$ \\
\hline 5 & 耳下腺管の拡張像 & \\
\hline
\end{tabular}

表 6 唾石の存在部位と治療法

\begin{tabular}{|c|c|c|c|}
\hline 症例 & 存在部位 & 治 療 法 & 後 \\
\hline 1 & 腺 体 内 & 経 過 観 察 & $\begin{array}{l}3 \text { 年間で大きさの } \\
\text { 変化なし }\end{array}$ \\
\hline 2 & 腺内主管内 & $\mid \begin{array}{l}\text { 口腔外ょり尊管を } \\
\text { 切して開し石を摘 } \\
\text { 出 }\end{array}$ & $\begin{array}{l}\text { 耳下腺機能良好, } \\
\text { 発なし }\end{array}$ \\
\hline 3 & $\begin{array}{l}\text { 腺 体 内 } \\
\text { 腺内主管内 } \\
\text { 耳下腺管内 }\end{array}$ & 耳下腺全摘出術 & $\begin{array}{l}\text { 顔面神経麻瘒なし } \\
\text { Frey 症候群なし }\end{array}$ \\
\hline 4 & 腺内主管内 & $\begin{array}{l}\text { 皮虐に自潰して自 } \\
\text { 然排出 }\end{array}$ & $\begin{array}{l}\text { 耳下腺部腫脤の, } \\
\text { 再発なし }\end{array}$ \\
\hline 5 & 耳下腺管内 & $\mid \begin{array}{l}\text { 口腔内より尊管を } \\
\text { 切して開し石を摘 } \\
\text { 出 }\end{array}$ & $\begin{array}{l}\text { 耳下腺機能良好, } \\
\text { 再発なし }\end{array}$ \\
\hline 6 & 耳下腺管内 & $\begin{array}{l}\text { 只腔内ょり導管を } \\
\text { 彴して開し石を摘 } \\
\text { 出 }\end{array}$ & 耳下腺機能良好 \\
\hline
\end{tabular}

RI 検査は 3 症例について ${ }^{99 \mathrm{~m} T c-p e r t e c h n e t a t e, ~}{ }^{67} \mathrm{Ga}-$

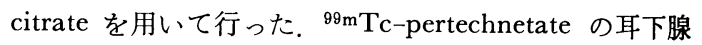
部への集積は唾液腺造影像での腺系の破壊像の程度に比 例して低下していた。 また， ${ }^{99 \mathrm{~m} T c-p e r t e c h n e t a t e ~}$ 集積 欠損部に ${ }^{67} \mathrm{Ga}$-citrate の異常集積像がみられた(図7〜 12).

唾石の存在部位と当科での治療（表 6)：症例 1 は経 過観察中. 症例 2 は腺機能がいまだ㸾められたため口腔 外より導管を切開して唾石の摘出を行った。導管はポリ エチレン管を捜入して縫合し保存した（図 13，14）。ボ リエチレン管は術後 1 週間目に拔去した。術後 1 か月目 の唾液腺造影では縫合部での導管の狭窄はなく, 腺系の 異常も改善されていた（図 15）。症例 3 は複数個唾石で しかも腺機能がほとんど廃絶していたため, 顔面神経を 保存して耳下腺の全摘出術を行った（図 16）。術後の顔 面神経麻疸は一時的には認められたが，すぐ改善しまた Frey 症候群の出現は認めていない，症例 4 は唾石の移 
動がみられたため, 経過観察を行ったところ経過観察中 に皮膚側に自潰し唾石は自然排出した。以後耳下腺部の 腫脹は認めていない。症例 5 は口腔内より耳下腺管を約 $1 \mathrm{~cm}$ 切開して唾石を摘出した。 以後再発は認めていな い. 症例 6 も腔内より耳下腺管を約 $7 \mathrm{~mm}$ 切開して 4 個の唾石を摘出した。 以後耳下腺機能は良好に保たれて いる.

\section{考察}

部位別, 年齢別, 性別発生頻度 : 耳下腺唾石症が全唾 石症に占める割合はこれまでの本邦の報告9,14 18) では 5 〜10\%，欧米での報告は 16\% (Heineke 1913) ${ }^{19) ， 20 \% ~}$ (Harrison 1926) ${ }^{20)}$, 12\% (Tholen 1949) ${ }^{21)}, \quad 0.7 \%$ (Seldin 1953) ${ }^{22)}$, 5\%(Husted 1953) ${ }^{23)}$, 10\% (Rauch 1959 24)である。しかし，当科での過去約15年間におけ る耳下腺唾石症の発生頻度は全唾石症 326 例中 6 例, 1.8 \%でありこれは本邦ならびに欧米の報告に比べ低い頻度 であった。

耳下腺唾石症の発症年齢はこれまでの報告1 41) では10 〜30歳代での発生頻度がいくぶん高いようではあるが, 各年代でほぼ均等に発生している。 今回の症例も推定発 症年齢は 8 歳, 11歳, 18歳, 45歳, 53歳, 62歳でとくに 年代別のかたよりはみられなかった。耳下腺唾石症と靧 下腺唾石症の年秢別発生頻度を比べてみると, 顎下腺唾 石症では20４0歳代にとくに高く，40歳代までに70\%近 くが発生して扣り ${ }^{42)}$, 耳下腺唾石症とは多少異なってい た。

性別発生頻度は本邦, 欧米ともに男性の方が発生率が 高い, ${ }^{911)}$ ようであるが，今回の当科での結果は男性 1 例, 女性 5 例で迎の結果であった。 耳下腺唾石症の症例数が いまだ少ないこと，顎下腺唾石症ではほとんど性差のな いこと 22,42 44)などを考えると性差については，いまだ結 論しえないのではないかと考えられた。

当科初診までの期間ならびに他科での診断, 治療: 当 科初診までの期間は 1 か月， 3 か月， 5 か月， 2 年， 5 年, 20 年とその期間には大きな差がみられた。 しかし, 当科持ける顎下腺唾石症の患者の初診までの期間が 3 か月以内 $45 \% ， 1$ 年以内 $64 \%$ であった ${ }^{42)}$ のに比べると耳 下腺唾石症の初診までの期間は長い上うである。 また当 科初診までの他科での診断では, 他科受診した 5 例中 1 例のみが耳下腺唾石症の診断がついているにすぎない点 を考えると，本疾患の診断は難しいようである，さらに その治療内容子消炎療法のみにとどまっていた。これら のことが，本疾患患者の初診までの期間を長くしている 原因の1つではないかと考えられた。

唾石の存在部位, 大きさ, 個数 : 唾石の存在部位とし ては一般に導管内の方が腺体内よりも頻度が高い, ${ }^{9,10)}$ うである. 今回の症例でも導管内の方が出現頻度が高
く, 同様の結果であった。 また導管内での部位別発生頻 度として腺体と耳下腺管の移行部にできやすいといら報 告11)がある. 今回の症例です 1 例に同様の部位に唾石を 認めたが，はたしてその傾向があるか否かについては定 かでなかった。両側性耳下腺唾石症の報告 ${ }^{11,45)}$ は欧米に おいてはみられるが，本邦ではいまだない，今回の症例 でも反対側には認められなかった。

唾石の大きさでは耳下腺唾石は顎下腺唾石に比べて小 さいとの報告9,11) があるが，今回の症例でも全例 $10 \mathrm{~mm}$ 以下であった。 このことは当科に却ける顎下腺唾石の大 きさが $10 \mathrm{~mm}$ 以上のものが $28 \%{ }^{42)}$ あることを考光れば やはり小型のものが多いと考光られる.

唾石の個数では, 耳下腺唾石は複数個唾石になりやす いとの報告 ${ }^{5}$ もあり，また複数個症例の報告 $5,7,15,25,26,29 \sim$ $31,34,35,41,46)$ もいくつかみられる. しかしながら今回の結 果は複数個例は 2 例であり, 当科に括ける頶下腺唾石の 複数個症例の出現頻度 ${ }^{42)}$ が約20\%であることを考劣れば 多少多い程度と考兄られた。 またこれまでの多数個症例 では唾石は大部分腺体内に認められている ${ }^{24)}$ のに対し, 今回の複数個症例では 1 例は腺体内, 耳下腺管内両方に 多発し, 他の 1 例は耳下腺管内に認められ, この点はこ れまでの報告と異なっていた。

臨床症状 : 耳下腺唓石症の病状として耳下腺部の腫 脹, 疼痛の報告 $6,8,25,26,29,41)$ や, 化膿性耳下腺炎の病像 をとった報告 $1,3,15,26 \sim 28,34,38)$ ，また慢性再発性耳下腺炎 の病像をとった報告 ${ }^{25,31)}$ などがあり多様である。しか し, その症状の程度については耳下腺唾石症では腫脹, 疼 痛などは顎下腺唾石症に比べて一般に軽い傾向にあると の報告 ${ }^{12)}$ ある. 今回の症例でも初発症状は腫脹が主で 疼痛は少なく，また明確な唾腫を訴えたるのが 1 例であ った点を考劣ると耳下腺唾石症ではその症状は一般に軽 いのではないかと考えられた。 さらに今回の症例の 6 例 中 2 例が急性炎症を起こさず慢性再発性耳下腺炎様の病 像を呈していた点, また当科初診時まで 1 例を除いてと くに強い症状がなかった点からも病状の程度は軽いと考 えられた。耳下腺唾石症の病状が軽い理由としてTurner $(1956)^{12)}$ は耳腺唾石では唾石による完全閉塞がなかな か起こらないためであろらと述べている。このことは耳 下腺唾石の大きさが小さい点, 形成速度が技そい点を考 えあわせれば, その可能性は十分ありらると考兄られた。

臨床検査: $\mathrm{X}$ 線単純撮影で今回の 6 症例は全例 $\mathrm{X}$ 線不 透過物が認められ，一応これまでの多くの報告 ${ }^{12)}$ と同様 本検査は唾石を確認するにあたって有効な検査法と考兄 られた。しかし, 耳下腺唾石はX線単純撮影では確認し にくい，または透過性の唾石も存在するとの報告 ${ }^{11,47) も ~}$ あり，X線単純撮影のみでは必ずしも確定診断はできな いとの報告 ${ }^{11,47)}$ ある。.この点は今回の症例でも頢下腺 唾石に比べると唾石の不透過性が低く，また唾石に近接 してフィルムを㯰けないためか, 周囲組織とのコントラ 
ストは必ずしもよくはない点を考えるとX線単純撮影の みでは小型の唾石は判別が難しいと推測された。ただ， このような周囲組織とのコントラストが悪い場合でも Xerography を用いるとかなりはっきりと確認できここ の点では本法はより確実に睡石を識別する上で有効な検 查法と考兄られた。

㕰液腺造影法による本疾患の診断の有効性について は，以前より多くの報告 ${ }^{11,48 \sim 50)}$ がある。 今回の症例で も検查を行った全例に唾石による陰影欠損像が認めら れ, 唾石の存在の有無と存在部位の診断に有用であっ た。またこのことはX線単純撮影にて判定しえない唾石 のスクリーニングにも本検査が有効であることを示㖫す る点と考兄られた。ささらに腺組織の破壊の状態がある程 度把握でき，手術法選択にあたって腺を保存するか否か の判定に有効な検査とも考えられた.

$\mathrm{RI}$ シンチ検査についてはこれまであまり報告 ${ }^{10)}$ がな く，本検査の有効性についてもいまだ定かでない，今回

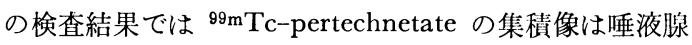
造影像による腺組織の状態とよく相関して括り, 腺組織 の機能状態が明瞭に把握でき, この点から本検查も手術 の際腺組織を保存するか否かの決定に有用であると考兄 られた。 ${ }^{67} \mathrm{Ga}$-citrate は唾液腺造影像で腺組織が破壊さ れている例では同部に異常集積像が認められ, ${ }^{99 \mathrm{~m} T \mathrm{~T}-}$ pertechnetate と併用すればより腺組織の状態を調べる 上で有效と考光られた。しかし， RI 検查の有效性につ いてはさらに症例を追加して検索する必要があると考兄 られる。

治療法 : 耳下腺唾石症の治療法は大別すると, 保存的 療法と外科的療法に分けられる。保存的療法としては唾 液分泌を促進させて自然排出させる方法 $5,26,34,36)$ や針子. で摘出する方法6,11,40) などの報告があり, ある程度の効 果をあげている，とくに唾液分泌を促進させる療法は耳 下腺唾石では疼痛などの症状が軽い点, また自然排出す ることがよくある点などを考えると，腺機能が十分あ り, 唾石が小型で, 比較的太い導管内に存在する場合は 有川 (1973) ら 5 の報告と同様に外科的治療法の前に一度 は試みるべき療法と考えられた。

外科的療法としては, 耳下腺管を切開して摘出する方 法と腺組織と一塊として摘出する方法がある。これまで の報告で最も多いのは口腔内より耳下腺管を切開して唾 石を摘出した報告 $1,3,9,12,25,28,31)$ である。 また， 口腔外よ り切開して唾石を摘出した療法の報告 $2,10,11,30)$ もくつ かみられる。しかし，耳下腺全摘出術を行った報告7,20, 51,52) は少ない上うである。外科的療法の招の扔のの適応 については New (1931) ら ${ }^{53)}$, Seward (1968) ら ${ }^{54)}$ は開 口部近くの唾石は口腔内より摘出し, 耳下腺腺体内の唾 石は口腔外より唾液腺の全摘出術を行うのがよいと述べ ている。 また, Harrison (1926) ${ }^{20)}$, Ivy (1932) ${ }^{51)}$ も耳 下腺管の前方の唾石は口腔内より摘出し, 腺体内の唾石
は耳下腺の摘出術を行った方がよいと同様の意見を述べ ている。綾仁ら $(1978)^{7)}$ は耳下腺浅葉内に散在した多 数個唾石症例に対し，耳下腺の亜全摘を行ったと報告し ている.

以上の報告と今回の症例上り考光, 外科的療法の各適 応としては，耳下腺管内唾石で咬筋前縁より開口部側の 唾石は口腔内ょり摘出し, 腺内主管ならびに耳下腺管内 で咬筋前縁より腺体側のものは口腔外上り摘出するのが 適当之考兄られた。耳下腺摘出術の適応症例は腺内の多 数個唾石症または唾液腺造影, RI シンチ検査にて腺機 能が全く破壊されている症例と考えられた。また耳下腺 唾石症の場命，経過钼察中に皮店側に自潰して唾石が自 然排出したり，唾液瘦を形成する場合 $1,7,27,30,31,35)$ もあ る。この場合は自潰部より唾石を摘出し，その後同部を スポンジとェラスティックバンドなどで圧迫しておくと 外唾液瘦も形成せず良好な結果が得られるようである。

鑑別診断：本疾患はまれな疾患であり，またX線単純 撮影にて唾石が必ずしも明確でなかったり，確認しえな いこともある点, さらに白覚症状があまり強くない点な どから診断にまよらことが多い。また X線単純撮影にて 不透過物を認めても，皮下結石 ${ }^{55)}$ や静脈石を伴った血管 腫 $\left.{ }^{33}, 56\right)$ との鑑別が時に必要なこともあり注意を要する。 それゆ光, 本疾患の診断には十分な臨床経過の聴取, 耳 下腺炎の有無の精查, 結石様硬結の触診, $\mathrm{X}$ 線単純撮影 ならびに耳下腺造影などを総合しての診断が重要である と考えられた。

\section{結語}

今回，われわれは1968年 1 月より1983年10月までの約 15年間に当科で診療した耳下腺唾不症について検索し, 以下の知見を得た

1. 検索症例は男性 1 例，女性 5 例で女性に多く，こ れまでの報告とは逆の結果であった。

2. 発症年齢は 10 歳代より60歳代までみられた。当科 初診までの期間は 1 か月， 3 か月， 5 か月， 2 年， 5 年, 20年であった。

3. 同期間中の 当科比ける 全唾石症中耳下腺唾石症 の発生頻度は $1.8 \%$ でこれまでの報告に比べ低かった。

4. 初発症状では全例に耳下腺部腫脹が みられたが, 程度は軽度であった。 また初診時症状では全例化膿性耳 下腺炎の病像を呈していた。

5. 唾石の存在部位は耳下腺管内 2 例, 腺内主管内 2 例, 耳下腺腺体内 1 例, 耳下腺腺体内, 腺内主管内, 耳 下腺管内に多発したもの 1 例であった。

6. 呚石の個数は 1 個症例 4 例, 複数個症例 2 例であ った。 また喠石の大きさは全例 $10 \mathrm{~mm}$ 以下であり，䫟 下腺唾石に比べて全般的に小型であった。

7. 耳下腺造影像では全例に㖊管の扗張像が，また経 
過の長い症例では腺系の破壊像がみられた。また，唾石 は陰影欠損像としてその存在部位が確認でき，本検査法 は本疾患の診断に有用であると考えられた。

8. RI シンチ検査は唾液腺造影像での腺系の破壊像

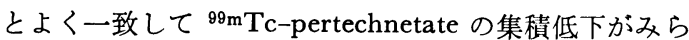
れ，腺組織の機能状態の精査法として有効であった。

9. 当科での治療法は，腺体内と腺管内に多発した症 例は耳下腺の全摘出術を，耳下腺管内で開口部に近い唾 石症例は口腔内より，遠い症例は口腔外よりの摘出術を 行いともに良好な結果を得た。 また腺管内唾石症例の 1 例は経過観察中に自潰して自然排出し, 以後耳下腺部の 腫脹は認めていない。

本論文の要旨は，第28回日本口腔外科学会総会 (1983) において発表した。

\section{引 用 文 献}

1）宇賀春雄：耳下腺管唾石症より誘発したと思わ れる急性化膿性耳下腺炎の 1 症例に就て。日本 畨科医師会学術会議会誌 3：71-72 1951.

2) 田島端夫, 片山公平: 稀有なる耳下腺排泄管唾 石症の 1 症例。臨床菌科 214：35 1956.

3）柘植精一，柴田寛一，他：耳下腺管唾石症の 1 例. 日口外誌 14：131-133 1968 .

4）兼田幸児, 江上富康：耳下腺唾石症の 1 治験 例. 山口医学 22: 173-174 1973.

5）有川正尋, 横山 潔, 他: 耳下腺内導管ならび に管唾石症の 1 症例. 日口外誌 19: 619-622 1973.

6）戸塚盛雄，古田 勲，他：耳下腺管唾石症の 2 例. 口病誌 43: 555-558 1976.

7）綾仁信夫, 島野圭司, 他：多発性耳下腺唾石 症. 耳喉 50：59-61 1978 .

8）北川博一，二見正人，他：耳下腺管内唾石症の 2 例。 日科誌 29：125-132 1980 .

9）川端五十鈴, 田中 寛, 他：耳下腺唾石症一 ならびに本邦に扣けるその統計的観察——耳 喉 53: 343-348 1981.

10）佐藤泰則, 高久 㩧, 他: 耳下腺唾石症の 1 例. 日口外誌 27：1456-1460 1981.

11) Blair, J.R. and Colo, D.: Diagnosis and treatment of parotid calculi. Laryngoscope 65: 848-854 1955.

12) Turner, H.: Salivary calculus in stenson's duct. OS OM OP 9: 830-832 1956.

13) Eskow, A.B.: A stone in the parotid duct. Report of a case. OS OM OP 9: 935-936 1956.

14）久保正雄：唾石症の統計的観察，耳喉 35：49511963.

15）田緑 昭，児玉图昭：過去 3 年間に打ける唾石 症の10例について.日口外誌 18: 341-346 1972.
16）五味武郎：本邦に於ける唾石の統計的観察。東 京医事新誌 2750: 2483-2491 1931.

17）小林信一：唾石症の統計。耳鼻 25：253-257 1979.

18）村上知子：顎下腺唾石症の 1 例並びにその統計 的観察. 耳喉 32: 71-73 1960.

19) Heineke, H.: Verletzungen und chirurgische Krankheiten der Speicheldrüsen. Deutsch Chir 33: 311-315 1913.

20) Harrison, G.R.: Calculi of the salivary glands and ducts. Surg Gyn Obst 43: 431-435 1926.

21) Tholen, E.F.: Sialolithiasis. J Oral Surg 7: 63-66 1949.

22) Seldin, H.M., Seldin, S.D., et al.: Conservative surgery for removal of salivary calculi. OS OM OP 6: 579-587 1953.

23) Husted, E.: Sialolithiasis. Acta Chir Scand 105: 161-171 1953.

24) Rauch, S.: Die Speicheldrüsen des Menschen. Georg Thieme Stuttgart 1959.

25）槙正男, 竹村文祥: 唾石の臨床的知見補遺 (1). 東京医事新誌 2742：2015-2018 1931.

26）大久保博舜：耳下腺唾石症例(抄)。 日耳鼻 50: 559-560 1944.

27）吉川久夫 : 稀有なる頓部の皮様囊腫と喠石を伴 った化膿性耳下腺炎症例。耳鼻臨床 44: 121 1951.

28）野木敏之：耳下腺唾石症例（抄）。聑鼻 57: 3901954.

29) 徳植 進, 岡本美二：耳下, 顎下両腺に現われ た稀有な唾石症 (抄). 口科誌 4：253 1955.

30）米丸年也：唾液瘦の治験(抄)。日耳鼻 59: 465 1956.

31）牟田実：唾液瘦を有する耳下腺唾石治験例 (抄)。日耳鼻 62: 14021959 .

32）堀越達郎, 土屋半七郎，他：唾石症の 5 例とそ の分析所見. 口外誌 8: 164-168 1962.

33）北村 武, 水流英雄, 他 : 耳下腺唾石症の 2 例 (抄). 日耳鼻 66: 15881963 .

34）大久保英子, 井端幸子，他：耳下腺結石の 1 症 例 (抄). 日耳鼻 69: 19881966 .

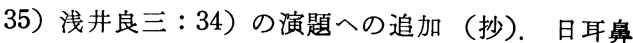
69: 19881966.

36）小林 泰：耳下腺結石症例と唾影法について (抄). 日耳鼻 67：935 1966 .

37）桑江良樹：最近経験せる唾石症の 2 例に就いて (抄)。 日耳鼻 69: 12321966 .

38）小林孝良, 緒方重郎：耳下腺唾石症（抄）。 日 耳鼻 71: 15321968 .

39) Kitamura, T., Togawa, K., et al.: Surgery of Stensen's duct. Arch Otolaryng 93: 1891931971.

40）桜井秀夫, 河野道男, 他 : 耳下腺管唾石症の 1 例 (抄). 口科誌 27: 5221978 .

41）野堀幸夫, 石橋利交:耳下腺唾石の 1 例(抄). 
日口外誌 27：292 1981.

42）左坐春喜, 篠原正徳, 他：唾石症の臨床統計的 検索，日口外誌 29：1304-1309 1983.

43）嶋本加寿子：顎下腺唾石症の臨床的観察. 耳鼻 臨床 68: 1133-1137 1975.

44）原利通, 福田健二, 他：唾石症の臨床統計的 及び病理組織学的観察. 日口外誌 25：106610721979.

45) Kessel, L.T., Schow, S.R., et al.: Bilateral parotid duct sialoliths. Oral Surg 40: 164-169 1975.

46）堺 哲郎, 丸山求蔵：唾石の摘出治験例 (抄). 東京医事新誌 3025: 6801937.

47) Langlais, R.P. and Kasle, M.J.: Sialolithiasis: The radiolucent ones. Oral Surg 40: 6866901975.

48) Yune, H.Y. and Klatte, E.C.: Current status of sialography. Am J Roentgenol Radium Ther Nucl Med 115: 420-428 1972.
49) Nichols, R.D.: Extraparotid disease,simulating parotid masses. Am Otol Rhinol Laryngol 81: 578-583 1972.

50) Blair, G.S.: Hydrostatic sialography an analysis of a technique. Oral Surg 36: 116-130 1973.

51) Ivy, R.H.: Salivary calculi. Ann Surg 96: 979-986 1932.

52）二宮知雄：唾石症の臨床的観察。臨床歯科 7: 723-756 1935.

53) New, G.B. and Harper, F.R.: Chronic inflammation of the salivary glands with or without calculi. Sur Gyn Obst 53: 456-460 1931.

54) Seward, G.R.: Anatomic surgery for salivary calculi. OS OM OP 25: 670-678 1968.

55）絲氏英吉，飯田 純：左耳下腺排泄管附近に2 られたる皮下結石の 1 例について. 日外会誌 56: 1141954.

56）堀川利彦：耳下腺唾石を思わしぬた静脈石につ いて。耳展 9: 48-50 1966. 

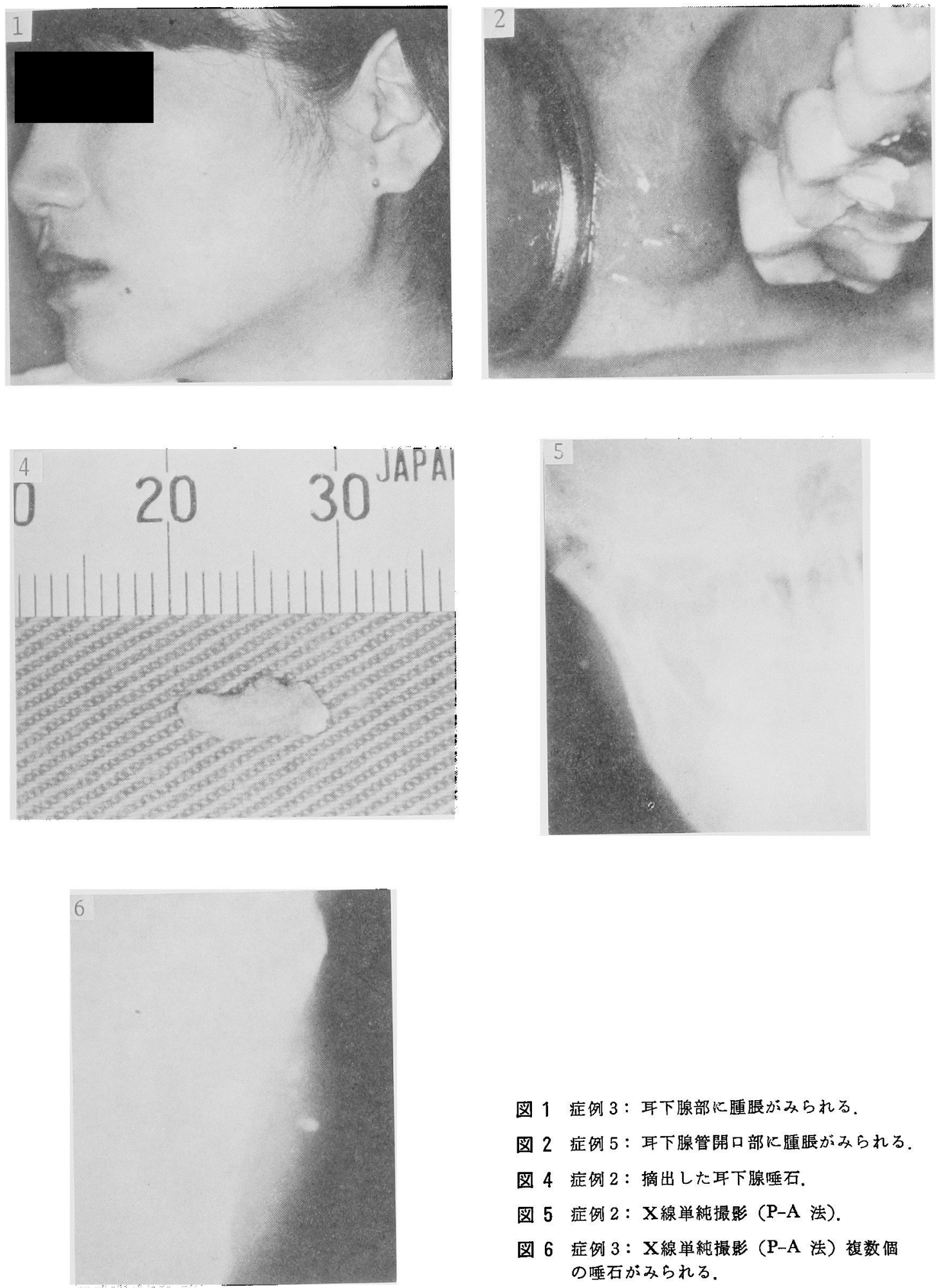

图 1 症例 3: 耳下腺部に腫脹がみられる。

図 2 症例 5: 耳下腺管開口部に腫脹がみられる。

図 4 症例 2 : 摘出した耳下腺聥石.

图 5 症例 2: X線単純撮影 (P-A 法).

图 6 症例 3: X線単純撮影 $(\mathrm{P}-\mathrm{A}$ 法) 複数個 の唾石がられる。 

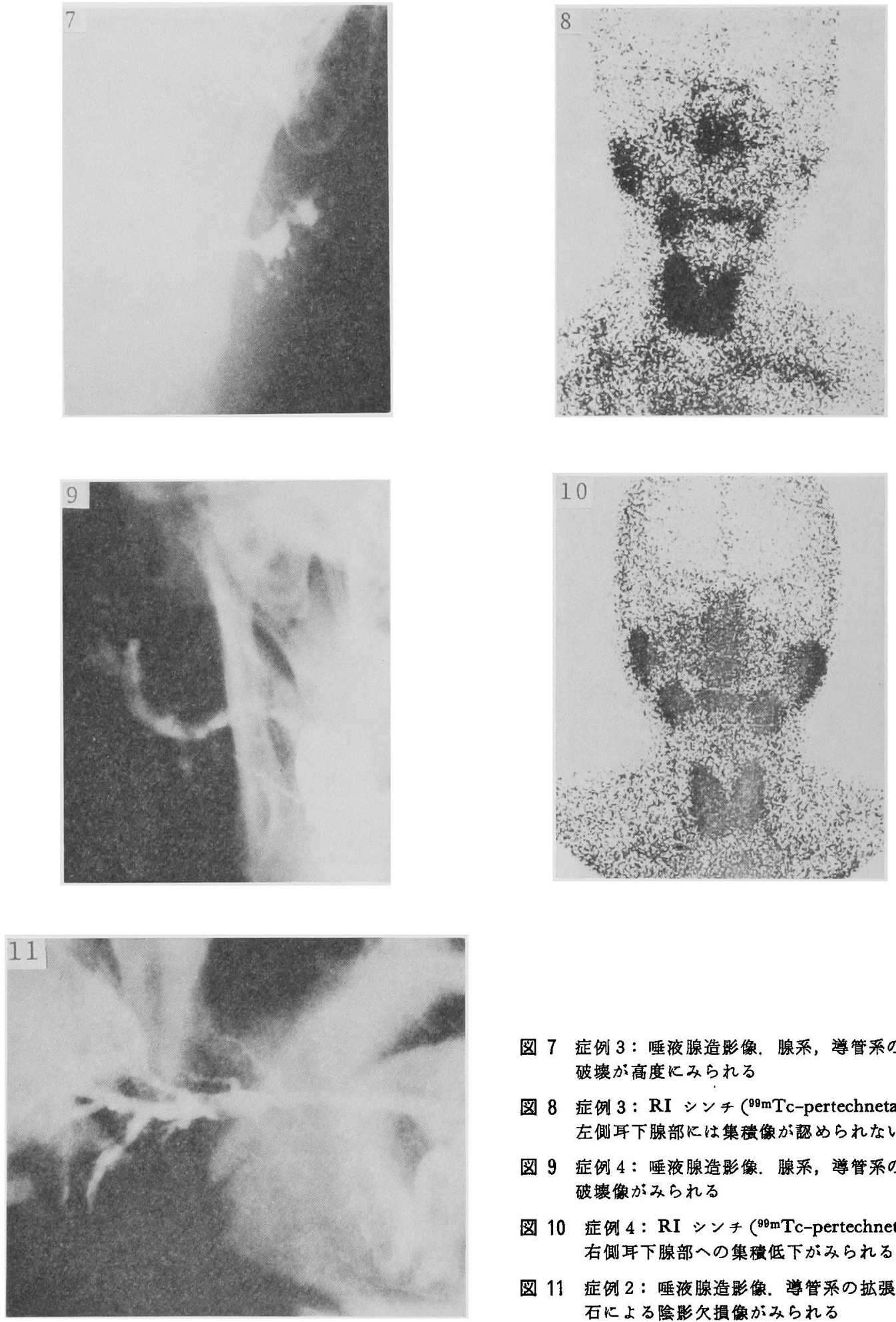

图 7 症例 3: 责液腺造影像、腺系，導管系の 破壊が高度にみられる

图 8 症例 3: RI シンチ ( ${ }^{99 \mathrm{~m} T c-p e r t e c h n e t a t e) . ~}$ 左側耳下腺部儿は集積像が認められない

図 9 症例 4: 無液腺造影像. 腺系, 導管系の 破壊像がみられる

图 10 症例 4：RI シンチ ( ${ }^{90 m T c-p e r t e c h n e t a t e) ~}$ 右側耳下腺部への集積低下がみられる。

图 11 症例 2：㕰液腺造影像，尊管系の拡張，唾 石による险影欠損像がみられる 

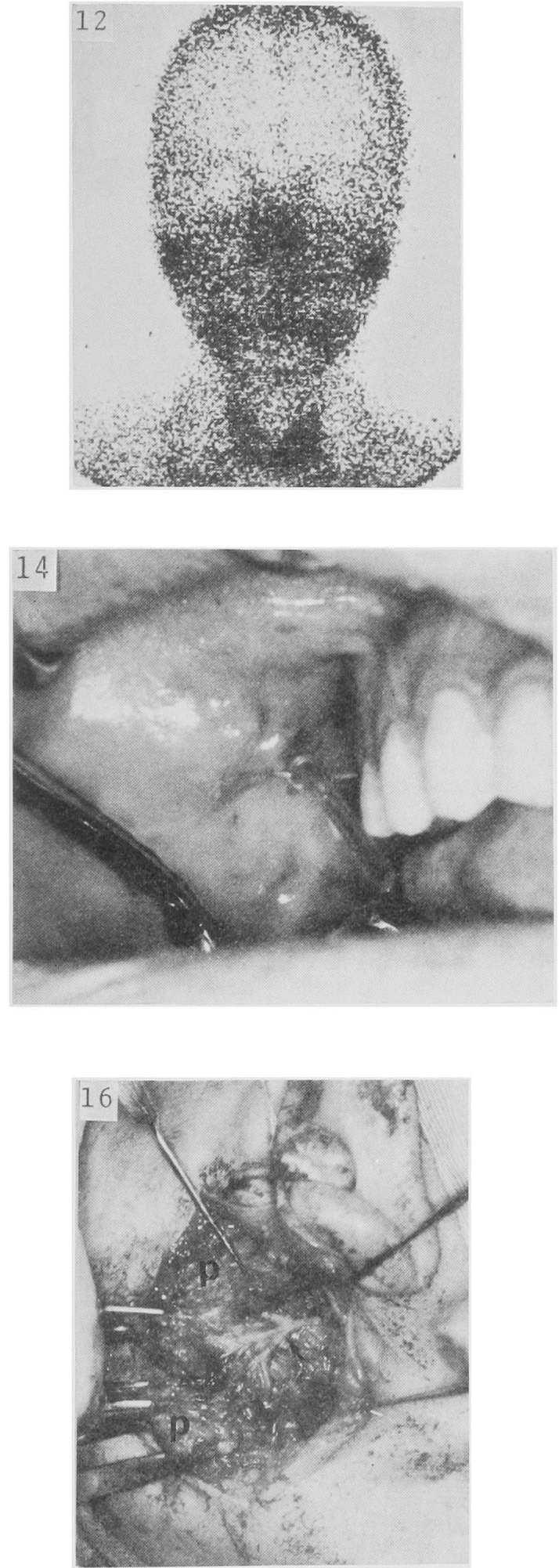
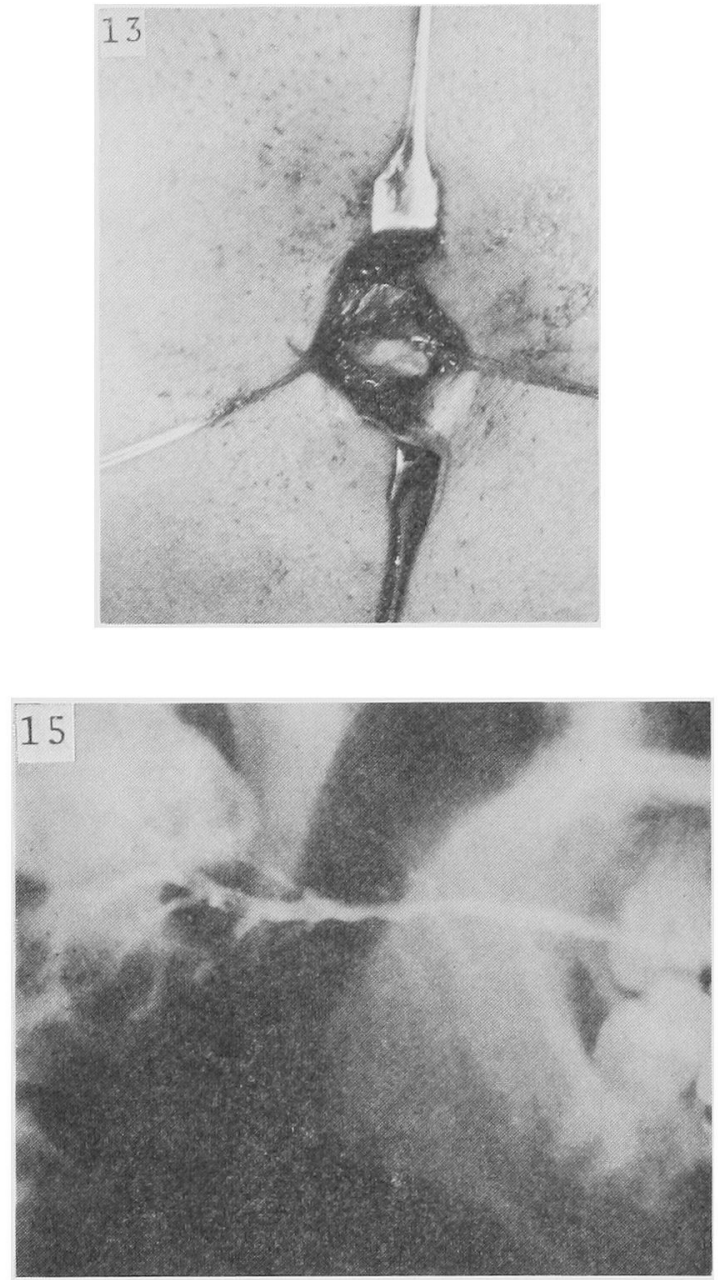

図 12 症例 2: RI シンチ ( ${ }^{99 \mathrm{~m} T c-p e r t e c h n e t a t e) . ~}$ 左右耳下腺部の集積像に差は認められない

図 13 症例 2：皮廂㑡より耳下腺管を团開し喠 石を摘出した。

図 14 症例 2：口腔内上り導管内にポリェチレン 管を插入し，導管を縫合した。

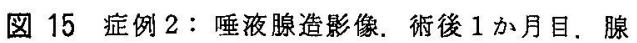
系の異常も改善されてきている.

図 16 症例 3 : 顔面神経 $(\downarrow)$ を保存して耳下腺 (P)の全摘出を行った. 